\title{
Suara-Suara Islam dalam Surat Kabar dan Majalah Terbitan Awal Abad 20 di Minangkabau ${ }^{1}$
}

\begin{abstract}
Sastri Sunarti ${ }^{2}$
Abstrak

Tulisan ini menjelaskan tentang perkembangan pers di Sumatera seperti Palembang, Medan, Sibolga, Padang, dan Kota Raja di Aceh pada paruh kedua abad ke-19. Namun demikian, tulisan ini fokus pada daerah Padang yang menjadi pusat perniagaan yang dikelola oleh orang Eropa (terutama Belanda) dan Tionghoa. Selanjutnya, pada awal abad ke-20, para pengusaha pribumi mulai terlibat dalam bidang percetakan dan penerbitan, seperti surat kabar Alam Minangkerbau (1904), Perserikatan Orang Alam Minangkerbau (OAM) tahun 1911 milik orang pribumi asal Minangkabau. Mulai saat itu usaha di bidang percetakan dan penerbitan semakin berkembang di Sumatra. Usaha ini pun hingga memunculkan berbagai karakter dan kepentingan masyarakat pribumi terutama tentang suara-suara kelompok atau organisasi yang memperjuangkan nasib masyarakat miskin, tertindas, maupun yang kurang mendapatkan pengajaran. Sampai menjelang pertengahan abad ke-20 suarasuara masyarakat semakin tumbuh dan direpresentasikan melalui berbagai media cetak. Banyak yang mengusung tentang pentingnya pendidikan baik umum maupun agama di samping tentang periklanan dari perusahaan-perusahaan perkebunan. Maka dari perkembangan pers inilah tidak sedikit yang mengawali suara nasionalisme bangsa dari berbagai wilayah di Indonesia termasuk dari Sumatera.
\end{abstract}

Kata Kunci: Pers Islam, Suara Nasionalisme, Minangkabau, Abad XX

\begin{abstract}
This article explains about the development of press in Sumatera, such as Palembang, Medan, Sibloga, Padang, and Kota Raja in Aceh in the second half of $19^{\text {th }}$ Century. However, it focuses on Padang as the center of commerce run by European (especially Dutch), and Chinese. In addition, in the beginning of $20^{\text {th }}$ Century, the indigenous petty bourgeoisie involved in printing and publishing sector, such as Alam Minangkerbau newspaper (1904), Perserikatan Orang Alam Minangkerbau (OAM) in 1911 owned by the local people from Minangkabau. Since then, printing and publishing business had been growing in Sumatera. The business brought various characteristics and also local people interests, especially the voices of groups or organization that fought for the poor, the oppressed people, and the ones who were lack of education access. Until the mid of $20^{\text {th }}$ century, the voices of the people was growing and represented through variety of printed media. Many of them carried on the importance of education, both general and religious education, as well as advertising and plantation companies. This development of press brought the voice of nationalism from various region, including Sumatra.
\end{abstract}

Keywords: Islamic Press, Voice of Nationalism, Minangkabau, $20^{\text {th }}$ Century

\footnotetext{
${ }^{1}$ Artikel ini merupakan hasil penelitian tentang Suara-suara Islam dalam Media yang dilakukan secara mandiri oleh peneliti.

2 Puslitbang Lektur dan Khazanah Keagamaan Badan Litbang dan Pusdiklat Kementerian Agama RI.
} 


\section{PENDAHULUAN}

Ahmat Adam $^{3}$ menjelaskan secara spesifik perkembangan pers di kota Padang. Menurutnya, kota Padang merupakan salah satu kota terpenting dalam pertumbuhan pers, terutama surat kabar, di Sumatera pada paruh kedua abad ke-19 selain Palembang, Medan, Sibolga, dan Kota Raja di Aceh. Kedudukan Padang menjadi penting karena pesatnya perniagaan yang dikelola oleh orang Eropa (terutama Belanda) dan Tionghoa. Perkembangan Padang sebagai pusat perniagaan di wilayah pantai barat ini kemudian juga didukung dengan dibukanya pelabuhan Emmahaven (sekarang Teluk Bayur) pada Oktober 1892. ${ }^{4}$ Pelabuhan ini berfungsi sebagai pelabuhan laut yang menjadi tempat penyaluran hasil bumi dari pedalaman Sumatera Barat dan Tapanuli Selatan untuk kemudian diteruskan ke seluruh Eropa terutama Belanda. Kota Padang saat itu menjadi titik temu para saudagar dari semua etnik dan memperlihatkan semacam karakter kosmopolitan. Di sinilah pers bisa menemukan rumahnya dan bertumbuh dengan subur.

Awalnya, perusahaan penerbitan yang terdapat di kota Padang dimiliki oleh pemerintah kolonial Belanda serta didirikan untuk menerbitkan surat kabar dan buku-buku dalam bahasa Belanda. Isinya antara lain berupa laporan-laporan administratif mengenai hasil perkebunan, pertambangan, dan pengamatan tentang daerah jajahan. Pada tahun 1859 diluncurkan majalah pertama

\footnotetext{
3 Ahmad Adam B. Sejarah Awal Pers dan Kebangkitan Kesadaran Keindonesiaan, (Jakarta: Hastra Mitra, 2003), h. 212.

${ }^{4}$ Freek Colombijn, Paco-Paco Kota Padang: Sejarah Sebuah Kota di Indonesia Abad ke-20 dan Penggunaan Tata Ruang Kota, (Padang: Ombak, 2006), h. 289.
}

di kota Padang dalam bahasa Belanda yakni Padangsche Nieuws-en Advertentieblad. Menurut Colombijn ${ }^{5}$, ini mungkin merupakan majalah pertama yang terbit teratur di Padang dan sebagian besar isinya hanya iklan. Kemudian berdasarkan hasil penelitian saya di Perpustakaan Nasional Republik Indonesia diperoleh keterangan tambahan mengenai majalah tersebut yang ternyata terbit hingga tahun 1863 . Penerbitnya adalah Wijk van Ram di kota Padang dan terbit setiap minggu.

Berdasarkan daftar majalah dan surat kabar yang berhasil saya catat di Perpustakaan Nasional Republik Indonesia, setidaknya terdapat kurang lebih 167 terbitan di seluruh Minangkabau pada terbitan awal (18591940an) tersebut. Lebih dari separuhnya terbit di kota Padang, sedangkan sisanya terbit di kota-kota lain di Minang seperti, Kayu Tanam, Pariaman, Padang Panjang, Fort de Kock (sekarang Bukittinggi), Payakumbuh, Fort van der Capellen (sekarang Batu Sangkar), dan Sawah Lunto. Jumlah ini lebih banyak dari jumlah data surat kabar dan majalah yang pernah disampaikan oleh Asma Naim dan Mochtar Naim ${ }^{6}$ yaitu hanya terdapat 118 koran dan majalah. Adapun surat kabar dan majalah berbasis Islam yang dapat diketahui dari judul dan nama serta tujuan penerbitan itu yang diterakan di halaman mukanya terdapat kurang lebih sebanyak 40-an judul yang masih tersimpan di Perpustakaan Nasional. Beberapa diantaranya adalah sebagai berikut. $A l$ Moenir, Al Itqan, Al-I'lam, Al Achbar, Al-Bajan, Al Insaaf, Al-Choetbah, AlMizan, Al-Djauharah, Al-Asjraq, Iqbahoel Haq, Al-Moenawwarah,

\footnotetext{
${ }^{5}$ Colombijn, Paco-Paco Kota Padang, h. 41.

${ }^{6}$ Asma Naim dan Mochtar Naim, Bibliografi Minangkabau, (Singapore: The Institute of Southeast Asian Studies, 1975), h. 6-9.
} 
Annoer Boeat Amal, Islam Djumaah Ahmadijah Qadian, Muslim India, Moeniroel Mannar, Noeroel Jaqin, Pewarta Islam, Penerangan Islam, dan Soera Moeslimin.

Keterlibatan pengusaha pribumi di bidang percetakan dan penerbitan di Minangkabau dimulai pada awal abad ke-20. Ditandai dengan munculnya surat kabar milik orang Minangkabau yang pertama yakni Alam Minangkerbau tahun 1904. Pemiliknya adalah dua orang haji yakni Haji Mohd. Salleh dan Haji Mohd. Amin. Upaya kedua tokoh tersebut kemudian diteruskan oleh Mahyoeddin Datoek Soetan Maharadja yang pada tahun 1911 mendirikan percetakan dan penerbitan Perserikatan Orang Alam Minangkerbau (OAM).

Selanjutnya, berturut-turut lahir pengusaha pribumi Minangkabau di bidang percetakan dan penerbitan dengan nama-nama sebagai berikut: Tja Endar Bongsu, Al Moenir, Drukkerij Soematra, Oost Indisch Boekhandel \& Drukkerij, T. Pen, Bemidelling Burreau Samsuddin Rassat, Persatuan Moeslim Indonesia, dan Gazaira di Padang, Minangkabau di Pariaman, Pemoeda Moehammadijah di Kurai Taji, Oesaha Djasa di Sulit Air, Saripado Drukkerij, Suara Moerid, Tandikat, dan Soeara Kaoem Ibu di Padang Panjang, Tsamaratul Ichwan, Serikat Keluarga Koto Gadang, Agam, N.V. Nusantara, dan Pustaka Ilmu di Fort de Kock, Soloksche Drukkerij di Sulit Air, Typ Kahamy di Sawah Lunto, Drukkerij L.M. Kabau Batang Agamweg, Limbago dan Eleonora di Payakumbuh.

Dapat dikatakan bahwa pada awalnya ketertarikan pribumi untuk memasuki dunia usaha percetakan dan penerbitan lebih didasarkan pada keinginan untuk menyuarakan kepentingan kelompok dan organisasi yang menjadi penaung atau pemodal usaha percetakan maupun penerbitan ini. Biasanya, tujuan surat kabar atau majalah ini diterbitkan sudah tertera di halaman depan dan dicetak di bawah nama surat kabar tersebut.

\section{Gerakan Kaum Muda dan Revolusi Mental di Bidang Pendidikan dan Keberaksaraan}

Pelopor media berbasis agama Islam pada masa awal percetakan dan penerbitan di Minangkabau ini dimotori oleh kelompok intelektual Muslim asal Minangkabau yang dikenal dengan sebutan kelompok Kaum Muda. Disebut demikian karena kelompok ini dianggap berbeda gerakannya dalam pengembangan agama Islam di Minangkabau dengan gerakan Kaum Tua (lebih bersifat tradisional dalam pengajaran agama).

Kehadiran kelompok Kaum Muda di ranah Minangkabau ini ditandai dengan kepulangan tiga orang tokohnya yang terkenal yakni Dr. Hadji Abdoellah Ahmad, Dr. Hadji Abdul Karim Amroellah (Ayah Hamka), dan Syekh Moehammad Djamil Djambek dari Universitas Al-Azhar, Kairo. Ketiganya merupakan murid dari Syekh Ahmad Chatib, seorang putera Koto Gadang yang menjadi guru agama Islam dan imam dari mahzab Syafii di Masjid al-Haram di Mekah. Walaupun ia tdak pernah kembali ke daerah asalnya, tetapi ia tetap mempunyai hubungan dengan daerah asalnya ini melalui mereka yang naik haji ke Mekkah dan belajar padanya dan kemudian menjadi guru di daerah asal mereka masing-masing.

Hubungan tersebut dipererat lagi dengan publikasi tulisan-tulisannya sendiri tentang persoalan yang dipertikaikan yang sering dikemukakan kepadanya oleh murid-muridnya dari 
Indonesia. ${ }^{7}$ Sebelum kepulangan ketiga tokoh Kaum Muda ini ke Minangkabau, Syekh Ahmad Chatib ini pernah menulis satu buku yang menyatakan bahwa adat berkemenakan di Minangkabau itu tidak sesuai dengan ajaran agama Islam dan harus diubah.

Bukunya ini mendapat tanggapan dari Kaum Adat yang diwakili oleh Datuk Sutan Maharadja salah satu tokoh pers dari Kaum Tua di Minangkabau. Demikian pula ketika ketiga tokoh Kaum Muda ini kembali ke Minang, berita kepulangan dan sepak terjang ketiga tokoh Kaum Muda ini dimuat pula dalam surat kabar Berito Minangkabau. ${ }^{8}$

Upaya pertama yang dilakukan oleh kelompok Kaum Muda ini sepulang mereka dari luar negeri adalah melakukan pembaharuan dalam bidang pendidikan. Beberapa tokoh Kaum Muda seperti Haji Abdul Karim Amrullah dan Haji Abdullah Ahmad pada tahun 1904 mulai ikut mengelola surau Jembatan Besi ${ }^{9}$, salah satu lembaga pendidikan tradisional yang masih ada ketika itu. Kehadiran ketiga tokoh Kaum Muda ini membawa pembaharuan dalam metode pengajaran di surau ini. Mereka mulai mengenalkan dan mengembangkan cara belajar dan mengajar yang tidak lagi hanya mengandalkan penjelasan dari guru saja sebagaimana cara belajar di surau tradisional Minangkabau selama ini; melainkan juga menyebarluaskan penggunaan buku bacaan sebagai sumber ilmu yang lebih penting, melakukan tabligh akbar ke berbagai pelosok seperti yang sering dilakukan

7 Deliar Noer, Gerakan Modern Islam di Indonesia (1900-1942), (Jakarta: LP3ES, 1982), h. 38-39.

${ }^{8}$ Berito Minangkabau, No. 10, Desember 1926, Th. I.

9 Noer, Gerakan Modern Islam di Indonesia, h. 52. oleh Hadji Abdul Karim Amroellah (Haji Rasul), dan Syaikh Moehammad Djamil Djambek, melakukan penerapan sistem berkelas di sekolah.

Adapun lembaga pendidikan Islam modern yang berdiri berkat anjuran dari Kaum Muda ini adalah Perguruan Soematra Thawalib yang merupakan pengembangan dari surau Jembatan Besi dan didirikan oleh Haji Abdoel Karim Amroellah, Dinnija School di Padang Panjang didirikan oleh Zainoeddin Labaij El Yoenoesij, Dinnijah Poetri juga di Padang Panjang didirikan oleh adik Zainoeddin Labaij yakni Rangkajo Rahmah El Yoenoesijjah, Al Tarbijah AlHasanah di Bukitinggi didirikan oleh Haji Latif Sjukur, Sekolah Adabiah di Padang dirikan oleh Haji Abdullah Ahmad dan ia mengadopsi model pendidikan Islam modern Iqbal di Singapura dan Perti (Perguruan Islam).

Pengaruh gerakan kaum Muda dalam bidang pendidikan agama Islam modern ini dapat kita ketahui dari kutipan surat kabar Berita Adat (1934) berikut ini:

Selain sekolah2 agamajg modern itoe, soerau2 tempat beladjar agama jg ada dikampoeng2poen melangkah poela kearah kemadjoean seperti pesantren di Parabek, di Djaho, di Padang Djapang, di Tandjoengbelingkoeng Solok, dll.

Gerakan Kaum Muda yang baru kembali dari Universitas Al-Azhar, Mesir dan juga Mekah pada awal abad ke-20 ini juga mengembangkan pengaruhnya di Minang melalui penerbitan surat kabar dan majalah yang akan kita bahas pada bagian selanjutnya.

Gairah keberaksaraan di kalangan intelektual muda muslim di Minangkabau juga dapat diketahui dari tingginya minat terhadap buku bacaan 
berbahasa Arab dan Mesir yang dikirim ke Minangkabau tahun 1916 dengan nominal fl.10.000 setahun. Buku-buku yang dikirim pada masa itu merupakan karya-karya standar intelektual dunia Islam seperti Al-Ghazali yang diterbitkan dalam dua bahasa yakni Arab-Melayu. Penyebaran buku-buku Islam juga dapat diketahui dari kioskios buku yang banyak tersedia di stasiun kereta api di Hindia Belanda dan surat kabar merupakan saksi hidup tumbuhnya organisasi yang berbasiskan agama, nasionalisme, sosial dan ekonomi pada masa itu. ${ }^{10}$

Tokoh Kaum Muda yang lain yang terlibat dalam dunia pendidikan dan penerbitan adalah Zainoeddin Labai El Yunusi. Berbeda dengan pembaharu lain pada zamannya, Zainoeddin Labai lebih tertarik pada kehidupan dan kegiatan tokoh-tokoh kebangsaan di dunia Islam seperti Mustafa Kamil dari Mesir daripada Abduh atau Rashid Ridha yang merupakan tokoh agama. Deliar Noer ${ }^{11}$ memberikan tokoh ini dengan kekaguman yang luar biasa berkenaan dengan upayanya memajukan pendidikan Islam modern di Minangkabau. Berikut pernyataan Deliar Noer terhadap tokoh ini:

"Dapat disebutkan bahwa dia adalah seorang autodidact, yang menjadi orang dengan tenaga sendiri. Penguasaan atas bahasa Belanda, dan Arab sangat membantunya. Koleksi buku-bukunya yang dapat penulis saksikan sendiri, meliputi kitab-kita yang ditulis di dalam bahasa-bahasa asing ini, dan meliputi berbagai macam bidang seperti aljabar, ilmu bumi, kimia dan agama, walaupun dalam aljabar dan kimia masih berupa kitab elementer...

\footnotetext{
${ }^{10}$ Abdurachman Surjomihardjo, dkk., Beberapa Segi Perkembangan Sejarah Pers di Indonesia, (Jakarta: Proyek Penelitian Pengembangan dan Penerangan RI, 1980), h. 76.

${ }^{11}$ Noer, Gerakan Modern Islam di Indonesia, h. 48-49.
}

Labai sendiri banyak menulis artikel dalam majalah Al-Munir yang terbit di kota Padang. Ia kemudian juga menerbitkan majalah dengan nama yang sama di Padang Panjang setelah Al-Moenir ditutup dan kantor percetakan mereka terbakar di kota padang . Berbeda dari pembaharupembaharu lain pada zamannya, Labai lebih tertarik pada kehidupan dan kegiatan kalangan kebangsaan, seperti Mustafa Kamil di Mesir, daripada Abduh atau Rashid Redha, yang lebih banyak memperhatikan soal-soal agama. Ia juga termasuk seorang yang mula-mula mengintrodusir sistem sekolah yang baru. Dengan membuka sekolah guru Dinniya (1915) ia mempergunakan sistem berkelas dengan kurikulum yang lebih teratur yang mencakup pengetahuan umum seperti bahasa, matematika, sejarah, ilmu bumi di samping pelajaran agama. Ia pun juga mengorganisir sebuah klub musik untuk murid-muridnya."

\section{Semangat Nasionalisme dalam Surat Kabar/ Majalah Islam}

Setelah Haji Abdullah Ahmad mendirikan lembaga pendidikan Adabiah di kota Padang tahun 1909 yang terilhami dari kunjungannya ke sekolah Al-Iqbal al-Islamiyah di Singapura dia pun mendirikan surat kabar. Sekolah Islam Al-Iqbal ini didirikan oleh Syeikh Thaher Jalaluddin al-Azhari salah seorang tokoh Kaum Muda yang paling senior dan menjadi guru juga bagi Haji Abdullah Ahmad dan kawan-kawan. Selain itu, Abdullah Ahmad juga sudah lama menjadi kontributor pada majalah Al-Imam yang peredarannya sampai ke Riau dan Minang. Ia pun mulai bergiat mendirikan surat kabar Islam pertama di Minang yakni Al-Moenir (19111916). 
Selain sebagai pengelola $A l$ Moenir dia ternyata juga menjadi agen bagi penerbitan surat kabar Islam $\mathrm{Al}$ Imam yang terbit di Singapura, AlManar, dan Al-Ittiqan yang terbit di Kairo. Sehingga tidaklah mengherankan jika penerbitan surat kabar Al-Moenir di kota Padang ini dipengaruhi oleh surat kabar Islam yang terbit di Mesir pada tahun 1908 yakni Al-Manar. Isi AlManar sangat banyak menyerukan persatuan umat Islam di dunia yang menjadi perhatian bagi Haji Abdullah Ahmad. Ia pun kemudian menerapkan model surat kabar $A l$ Manar di Al-Moenir. ${ }^{12}$ Adapun tujuan pendirian majalah Al-Moenir ini adalah sebagai berikut:

"Pemimpin dan pemajukan anak-anak bangsa kita...pada agama yang lurus dan beri'tikad yang betul ...dan menambah pengetahuan yang berguna dan mencari nafkah kesenangan hidup supaya sentosa pula mengerjakan suruhan agama”.

Selain itu majalah ini juga bermaksud berusaha ke arah berkekalan damai sentosa pada antara sama-sama manusia pada kehidupan...' Juga untuk mempertahankan Islam terhadap segala tuduhan dan salah sangka."13

Majalah Al Moenir di kota Padang ini, terbit dua kali seminggu dengan aksara Jawi. Isinya antara lain memuat artikel yang mempunyai tujuan untuk meningkatkan pengetahuan para pembacanya. Jenis artikel yang dimuat antara lain: perlunya beragama, biografi Nabi Muhammad, pengertian tentang mahzab, perlunya hisab dibandingkan ru'yah dan masalah duniawi, seperti kegunaan surat kabar dan majalah, kegunaan organisasi, serta kejadiankejadian di luar negeri, terutama di Timur Tengah. Umumnya Surat kabar

\footnotetext{
${ }^{12}$ Noer, Gerakan Modern Islam di Indonesia, h. 41-42.

${ }^{13}$ Al-Munir, Th.1, No.1, 1 April 1911, hlm 5.
}

dan majalah Islam seperti ini menyediakan "ruang" untuk tulisan yang memuat perdebatan ilmu agama, sosial, dan politik.

Pembaca sasaran dan khalayak andaian $^{14}$ majalah Al-Moenir adalah Engku-Engku dan Tuan-Tuan yakni sapaan yang digunakan kepada lelaki dewasa di Minangkabau pada masa itu.

Isi majalah Al-Moenir sering mengkritik pemerintah Hindia Belanda sehingga dianggap menghasut dan menyebabkan Al-Moenir mendapat pengawasan dan tekanan dari pemerintah kolonial dan akhirnya dilarang. Kantornya pun kemudian juga mengalami kebakaran yang hebat danmenyebabkan usaha percetakan $\mathrm{Al}$ Moenir berhenti beroperasi pada tahun 1916. Ada indikasi, kebakaran ini disengaja karena Al-Moenir dianggap mengobarkan sikap anti pemerintahan Hindia Belanda pada masa itu.

Beberapa pendiri Al-Moenir dikemudian haripun sempat dipenjara oleh pemerintah Hindia Belanda dan berita penangkapan pengurus $\mathrm{Al}-$ Moenir dimuat dalam surat kabar $\mathrm{Al}$ Ittqan 1918. Van Ronkel menilai Haji Abdullah Ahmad sebagai seorang yang lebih ahli di bidang penulisan dibandingkan sebagai guru agama. Walaupun ia tidak dinafikan sebagai seorang yang alim dalam ilmu agama Islam. Namun nampaknya ia lebih berbakat sebagai penulis sehingga Taufik Abdullah memberinya gelar sebagai Bapak Jurnalistik Islam Sumatera yang pertama. ${ }^{15}$

Ketika Al-Moenir di kota Padang

\footnotetext{
${ }^{14}$ Amin Sweeney, A Full Hearing: Orality And Literacy In The Malay World. (Berkeley: University of California Press, 1987).

${ }^{15}$ Gusti Asnan, "Pers Islam Di Sumatera Barat Pada Awal Abad XX: Suatu Gerakan Tinjauan Dalam Hubungannya Dengan Gerakan Pembaharuan". (Skripsi Sarjana S-1 Jurusan Sejarah, Fakultas Sastra Universitas Andalas Padang, 1987), h. 45.
} 
ditutup karena kebakaran dan juga ancama dibeslag karena isinya yang keras terhadap pemerintah Hindia Belanda, Zainuddin Labai meneruskan penerbitan majalah Al-Moenir ini di Padang Panjang dengan nama yang mirip yakni Moeniroel Manar atau AlMoenir Padang Panjang (1918-1922). Penggagas lain berdirinya Moeniroel Manar dan juga Al-Basyir adalah Haji Abdul Karim Amrullah. Tokoh ini sebelumnya merupakan salah seorang pembantu redaksi di majalah $\mathrm{Al}$ Moenir. ${ }^{16}$

Ketika masa jayanya, Al- Moenir juga memiliki usaha perceta- kan yang diperlukan oleh perkantoran dan perdagangan. Iklan-iklan percetakan milik Al-Moenir sering muncul dalam surat kabar Oetoesan Melajoe, Soenting Melajoe, dan Tjaja Soematra yang sezaman dengan Al-Moenir. Al-

Moenir memberi porsi yang besar kepada tulisan yang bertemakan pengetahuan tentang agama Islam, persatuan umat Islam, hukum-hukum agama serta kaitannya dengan adat dan budaya Minang.

Berikut foto setumpuk majalah Al-Moenir yang masih tersimpan sebagai koleksi majalah langka di Perpustakaan Nasional Jakarta.

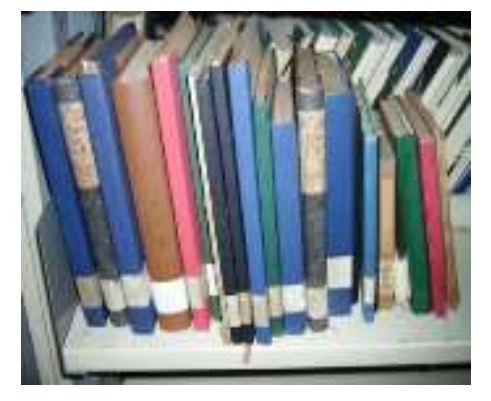

Foto 1. Majalah Al-Moenir

Semangat nasionalisme yang

${ }^{16}$ Asnan, "Pers Islam Di Sumatera Barat Pada Awal Abad XX: Suatu Gerakan Tinjauan Dalam, h. 45. sedang tumbuh dan gencar diberitakan oleh media cetak di luar negeri seperti di Mesir dan India juga menjalari semangat para pendiri dan pengurus majalah Islam di Minangkabau. Tetapi peraturan dan pengawasan yang ketat dari pemerintah Hindia Belanda membuat mereka menuliskan isu kemerdekaan dengan cara yang hati-hati dan tersamar. Umpamanya tulisan tentang kemerdekaan yang dimuat dalam Al Moenir awalnya bukan mengenai apa yang berlaku di Hindia Belanda melainkan kemerdekaan di negeri-negeri asing seperti Turki, Mesir, dan India.

Tetapi kita dapat menangkap makna tersirat tulisan itu adalah untuk menumbuhkan kesadaran pembaca di Hindia Belanda yang masih terjajah. Demikian juga dalam satu tulisan yang dimuat dalam Al-Itqan pada awalnya hanya sepertinya membicarakan ilmu pengetahuan tetapi akhirnya adalah membahas bagaimana mencapai kemerdekaan.

Meski tidak secara terangterangan mengecam pemerintah kolonial Belanda; beberapa tulisan yang dimuat dalam surat kabar berbasiskan Islam tahun 1920-1930an terutama sudah berani menyuarakan kemerdekaan jika dibandingkan dengan surat kabar lain yang sezaman pada masa itu. Umumnya isi majalah Islam ini lebih kritis mengkritik pemerintah jika dibandingkan dengan Bintang Timoer, Soenting Melajoe, Oetoesan Melajoe, dan Tjaja Soematra yang sezaman dengan Al-Moenir, Al Itqan, Al-Bajan, At-Tarbijah.

Ciri lain yang membedakan surat kabar dan majalah ini jika dibandingkan dengan surat kabar lainnya yang sezaman adalah mempertahankan penggunaan aksara Arab Melayu dalam penerbitan mereka. Ada yang khusus hanya menggunakan 
aksara Arab Melayu tetapi ada juga menggunakan aksara Latin atau campuran kedua-duanya seperti Majalah Al-Ittqan.

Retorika yang lebih tersamar dalam menyampaikan semangat kemerdekaan sudah dimulai dalam tulisan-tulisan yang dimuat dalam surat kabar dalam majalah yang terbit sepuluh tahun 20-an. Penulis dalam majalah $\mathrm{Al}$ Itqan $^{17}$ mencantumkan berita mengenai peperangan yang tengah terjadi di Eropa (Perang Dunia I) dan banyak menewaskan jutaan manusia yang didasari oleh semangat dan kewajiban mempertahankan kedaulatan bangsanya. Semangat kepahlawanan yang diperlihatkan bangsa Eropa dalam Perang Dunia I tersebut dinilai oleh penulis Al-Itqan sebagai sesuatu yang belum sesuai untuk ditiru dan dilakukan di Hindia Belanda pada masa itu. Sebaliknya jika ingin menjadi pahlawan pada masa itu menurut si penulis cukup dengan anjuran berikut:

"Manoesia mati meninggalkan namanja. Gadjah mati meninggalkan gadingnja. Harimau Mati meninggalkan belangnja”

"Hanja kalau betoel-betoel kita maoe tjari nama jang dirasa kelak bisa mendjadi poesaka bagi anak tjoetjoe kita, awal permoelaan tjoekoeplah doeloe toean-toean bekerdjalah goena keselamatan omoem, tjintailah bangsa dan tanah ajer dengan djalan jang tidak meliwati garisnja wet pemerentah, adat dan sjara', didiklah anak kemenakan kita soepaja melengket pada hati dan djantoengnja darah kebangsaan dan kemanoesian."

Kutipan tulisan di atas
merupakan sebuah pesan yang
mengandung ajakan kepada pembaca
agar tidak bertindak melanggar aturan
yang telah ditetapkan oleh pemerintah
Hindia Belanda. Himbauan dalam
tulisan tersebut seolah-olah
memperlihatkan ketaatsetiaan para

${ }^{17}$ Majalah al-Ittqan, 20 November 1922. penulis dalam majalah ini kepada pemerintah Hindia Belanda tetapi sesungguhnya mengandung pesan perjuangan melawan penjajahan tanpa kekerasan di Hindia Belanda.

Pada tahun 1930-an, semangat pergerakan sudah mulai secara terangterangan disebarkan di kalangan rakyat Hindia Belanda melalui surat kabar dan majalah. Berita-berita tentang negerinegeri di luar Hindia Belanda seperti perjuangan kemerdekaan di Mesir, India, dan perlawanan Cina terhadap penaklukan bangsa Jepang menjadi inspirasi bagi penulis di majalah $\mathrm{Al}$ Moenawwarah ${ }^{18}$.

Sebuah artikel yang berjudul "Kegontjangan Eropa, Kesadaran Asia" mengungkapkan api semangat kemerdekaan di negera-negara luar terhadap penjajahnya juga menyalakan api dan semangat kaum pergerakan di Hindia Belanda yang waktu itu sudah tergabung dalam partai-partai politik yang mulai tumbuh sejak tahun 1920an. Semakin kuatnya tuntutan untuk merdeka dari bangsa Indonesia tentu saja tidak luput dari pantauan dan pengawasan pemerintah Hindia Belanda sehingga banyak pengelola surat kabar dan penerbitan yang dicurigai bahkan ditangkap dengan semena-mena.

Beberapa surat kabar mengalami pembreidelan sebagaimana berita yang dimuat dalam Al-Munawwarah (1934) tersebut. Hal ini tidak hanya berlaku di Minangkabau saja melainkan juga terjadi pada pimpinan media cetak di wilayah lain seperti Pewarta Deli di Medan pada tahun yang sama.

Satu artikel lain yang juga pernah membahas isu kemerdekaan ini dimuat dalam majalah Al-Moenawwarah ${ }^{19}$. Pada saat tulisan ini diterbitkan

\footnotetext{
${ }^{18}$ Majalah Al-Moenawwarah, No. 5, Th. I, 15 Juni 1934.

${ }^{19}$ Majalah Al-Moenawwarah, No. 5, Th. I, 15 Juni 1934.
} 
keinginan untuk mencapai kemerdekaan itu sudah diwujudkan melalui usaha pergerakan. Tulisan ini menceritakan romantika yang terjadi dalam sebuah rumah tangga antara suami dan istri yang tidak sepakat dalam hal memandang pentingnya terlibat dalam dunia pergerakan kemerdekaan Indonesia. Dalam hal ini tokoh istri adalah pihak yang pro dan peduli pada upaya pergerakan dibandingkan dengan suami yang lebih mementingkan ketentraman rumah tangganya. Berikut kutipan artikel tersebut:

\section{Hidoep dalam Pertikaijan Faham!}

"Hari Senin tg 23 Ramadhan 135...kira-kira poekoel 7 sendja „Zahara” demikianlah nama seorang perempoean, tinggal disatoe negeri dekat Solok, jang sedang menjoesoen boekoe 2 dan soerat2 jang akan dibawanja ke vergadering, karena hari itoe adalah „receptie” besar oentoek pemboekaan rapat tahoenannja jang ke III, sedang Zahara terhitoeng satoe spreekster jang akan memberi verslag dalam receptie itoe. Diwaktoe Zahara sedang menghadapi tjermin besar oentoek membetoelkan koedeong moekanja, maka kedengaran satoe soera dari dalam...hendak kemana poela kau Zahara? Boekankah ini malam kita akan pergi ke roemah engkoe Santing, membitjarakan perkara tempo hari?? Dengan hormat Zahara mendjawab, saja maoe pergi menghadiri receptie engkoe! Apa Sepsi2, dan dari doeloe saja katakan kau tidak boleh pergi ke Vergadering, tapi sepeninggal saja kau pergi djoega, demikianlah kata Amran [soeami dari Zahara dimana dia terkenal sebagai katjang miang dalam pergerakan]. Karena ito ini hari djoega kau tidak boleh pergi kesepsi itoe, dan kalau kau pergi djoega, nanti djangan...."

Demikian gambaran pertikaian yang terjadi dalam rumah tangga pada masa itu akibat ketidaksepakatan terhadap pentingnya pergerakan kemerdekaan. Tulisan ini merupakan ilustrasi terhadap situasi yang dihadapi oleh tokoh-tokoh pergerakan kemerdekaan dalam menjalankan citacita perjuangan kemerdekaan pada masa awal dimulainya pergerakan ini. Khalayak sasaran yang hendak dicapai oleh penulis ini adalah para pembacanya yang berjuang dalam pergerakan kemerdekaan terutama khalayak sasaran perempuan yang mendapat tantangan dari suami untuk terjun ke dalam dunia pergerakan. Ancaman retaknya rumah tangga, pengorbanan harta, waktu, bahkan dipenjara merupakan tantangan yang akan dihadapi oleh orang-orang yang aktif dalam dunia pergerakan pada masa itu seperti yang dicontohkan dalam tokoh Zahara dan Amran dalam AlMoenawwarah ini. Tulisan ini juga bisa dilihat sebagai kritikan terhadap lelaki (terutama suami) yang tidak mendukung istrinya terlibat dalam organisasi pergerakan. Disini semangat perempuan menjadi tauladan dalam persiapan perjuangan kemerdekaan Indonesia.

Pada tahun 1934, di wilayah Solok misalnya, kita mendapatkan sebuah berita yang memuat pemberangusan sebuah majalah bernama Al-Moenawwarah. Pemberitaan yang sifatnya pemberitahuan kepada pembaca dan pelanggan surat kabar ini masih sempat dimuat dalam Al-Moenawwarah (No. 5, Th. I, 1934). Berikut berita pemberangusan majalah tersebut.

Ma'loemat Oemat Islam dan Rajat
Indonesia!
Almoenawwarrah" No 4
Dibeslag
Pagi2 hari Senin kira2 pk.6 telah datang ke
Drukkerij (Soloksche Drukkerij) (dimana
tempat mentjetak Al MOENAWWARAH) atas
nama Hoofd van Plaatselijk Besturr Solok:
(Tulisannya namanya tidakjelas)
Telah memberitahukan kepada kita (A.M.
Thalib) sebagai pengemoedi ,Al-
MOENAWARRAH”. Bahwa kedatangan wakil
pemerintah itoe , ialah datang, oentoek
membeslag ,Al MOENAWARRAH” No. 4,
perintah itoe tidakdapat kita pertahankan hanja
kita toereot sadja.
„Al-MOENAWARRAH” jang soedah tersedia 
boeat dikirim kepada adress masing2 abones, dan agent 2 jang soedah dipak, diband, semoeanja 1000 ex. Kita tidak melakoekan apa2 hanja sabar dan tawakkal kepada Allah. Hanja kita terima satoe soerat jang sebagai kwitatntie jang boenjinja: Dibeslag dari A.M Thalib, Soelit Air 700 (Toedjoeh ratoes boeah madjallah „Al-MOENAWARRAH” ddo. 15 Mei 1934 No 4boeat diperiksa isinja lebih djaoeh. Dan dibeslag dari M. Sjafe'ioeddin jang akan dibawa ke P. Pandjang 300 (tiga ratoes) boeah majalah ,Al-MOENAWARRAH”.

Solok 21 Mei 1934.

Namens het Hoofd van Plaatselijk Bestuur, De Mantri Politie

Penerbit „Al Moenawwarrah” OSAHA DJASAS.AIR.

Setara dengan berita yang di atas, di Bukittinggi pada tahun 1932 juga dimuat sebuah berita penangkapan seorang tokoh pergerakan yang amat disegani pada masa itu. Tokoh ini dikenal luas di kalangan saudagar sebagai salah seorang pendiri Bank Nasional dan juga pemilik percetakan N.V. Nusantara kemudian pendiri dan pemilik Hotel Minang di Padang, Bukittinggi dan Singkarak sesudah kemerdekaan. Berita penangkapannya dimuat dalam Dagblad Berita (Oktober 1932). Berikut kutipan berita penangkapan tuan Anwar Sutan Saidi:

\section{Penangkapan Toean Anwar}

Pada hari Minggoe 18 September 1932 poekoel 1 siang, sedang toean Anwar ada di fabriek saboennja, maka datanglah onderdercommissaris van politie dan onderdistrictshoofd akan melakoekan pentjoekaian diroemah dan dikantor.

Pentjokaian dilakoekan beramai-ramai, hadir semoeanja ondercommicis assistent wedana politie. Semoea boekoe-boekoe dibeslag. Begitoe djoega soerat-soerat.

Di kantor dibeslag beberapa soerat kabar, soerat-soerat dan beberapa soerat-soerat dan boekoe kepoenjaan Bank Nasional (Aboen Saudagar). Sesoedah itoe toean Anwar dibawa ke commissariat dan dari sana setelah ditanja ini dan itoe, dibawa ke tempat veldpolitie, dimana ia ditahan 18 djam, lamanja. Tangannja dibelanggoe sebelah dan sebalah lagi diikatkan ke terali beranda. Ia tjoema memakai badjoe kaoes dan tjelana pandjang sadja. Jang ditanja jaittoe apa dia ada mendapat soerat dari loear negeri, terotema Straits. Dan adakah dia berkenalan dengans eorang Djama.

Contreleur Fort de Kock kemoedian memberi keterangan, bahwa penahanan toean Anwar tidak bersangkoetan dengan sesoeatoe perkara melalinkan tjoema oentoek diperiksa berhoeboeng dengan perintah Procureur Generaal dalam sesoeatoe hal jang mesti dirahsiakan.

Setelah 18 djam lamanja toean Anwar ditahan, maka iapoen dilepaskan danssegala boekoeboekoe dan soerat-soerat dikembalikan. Bersama dengan dia ada poela doea orang lain di Boekit Tinggi jang menderitakan sematjam itoe djoega. Begiotoepoen di Padang Pandjang seorang toean Adam, dan di Koto Lawas seorang poeteri Noersiam.

Di Medan Toean Djamaloeddin hoofdredacteur Pewarta Deli kena geledah poela, akan tetapi tidak ditahan, melainkan tjoema tidak boleh ke loear kota.

Kehadiran surat kabar dan majalah-majalah Islam lainnya di Minangkabau juga mendapat sokongan murid-murid sekolah Islam yang tumbuh dengan pesat pada masa itu. Seperti Perguruan Sumatera Thawalib Padang Panjang, Dinnija Putra dan Putri juga di Padang Panjang, Adabiah di kota Padang, Batu Sangkar, Payakumbuh, Solok, dan Pesisir Selatan. Dalam berita surat kabar Al-Ittqan (1922) dijelaskan bahwa Perguruan Thawalib Padang Panjang pada tahun 1920-an memiliki murid hingga 1300 orang. Surat kabar Islam ini kemudian mendorong lahirnya persatuan guru-guru Agama Islam di Minangkabau. Kelompok inilah yang merupakan pembaca potensial majalah dan surat kabar Islam yang ramai terbit pada masa awal itu.

Persatuan Muslimin Indonesia (PERMI, 1929) adalah satu contoh organisasi politik yang muncul dari persatuan guru-guru agama yang merupakan pembaca dan pelanggan setia surat kabar berbasis Islam ini. Anggota PERMI kebanyakan berasal 
dari alumni sekolah Perguruan Sumatra Thawalib Padang Panjang. Pada tahun 1932, PERMI secara resmi menjadi partai politik dan beberapa tokohnya yang terkenal adalah Ilyas Ya'kub, Muchtar Luthfi, dan Gaffar Ismail (Ayahanda penyair Taufiq Ismail).

Sekitar tahun 1933 PERMI banyak mendapat tekanan dari Belanda dan pemimpin-pemimpinnya kemudian banyak dibuang keluar Minangkabau oleh pemerintah Belanda. ${ }^{20}$ Salah satu tokoh PERMI yang dibuang itu termasuk ayahanda Taufiq Ismail yang memilih tinggal di Pekalongan pada masa pembuangan itu. Mantan anggota PERMI ini kemudian dalam pembuangan masih gencar mendukung perjuangan pergerakan kemerdekaan melalui tulisan-tulisan mereka ke media di Timur Tengah. Salah seorang tokohnya adalah Ibunda Taufiq Ismail yang kemudian ikut menyuarakan pengumuman kemerdekaan Indonesia melalui siaran radio dalam bahasa Arab.

\section{Semangat Pan Islamisme}

Semangat Pan Islamisme juga tercermin dalam tulisan yang dimuat oleh majalah dan surat kabar berbasis Islam ini yang sering sekali menyerukan adanya persatuan umat Islam sedunia. Beritanya misalnya dapat kita baca dalam majalah Al-Ittqan. ${ }^{21}$ Demikian juga dalam majalah Islam di Pulau Jawa bernama Medan Moeslimin yang terbit di Surakarta pada tahun 1920-an juga menyuarakan semangat Pan Islamisme ini.

Semangat Pan Islamisme ini terlihat pada pemilihan berita yang banyak berkiblat kepada perkembangan

\footnotetext{
${ }^{20}$ Noer, Gerakan Modern Islam di Indonesia, h. 57-61.

${ }^{21}$ Majalah al-Ittqan, No. 3, Th. IV, 7 November 1922.
}

Islam di Timur Tengah dan negaranegara Islam lainnya di dunia. Islam danKemajuan merupakan salah satu topipk yang banyak kita jumpai dalam pers berbasis Islam di Hindia Belanda pada saat itu. Semangat Pan Islamisme itu juga tergambar dalam sumbersumber referensi buku dan ahli kitab yang banyak mengacu kepada intelektual Muslim masa itu seperti AlGazali, Abduh, dan Rashid Reza. pemilihan nama majalah dan surat kabar yang terbit di Minangkabau yakni menggunakan nama majalah dan surat kabar yang pernah terbit di Mesir atau di Mekah. Misalnya, surat kabar Al-Ittqan yang berdiri di Maninjau tahun 1918 (ketua redaksinya Haji Abdul Madjid) meniru nama $\mathrm{Al}$ Ittqan yang pernah terbit di Kairo. Demikian juga Al-Moenir mengambil nama yang sama dari majalah yang juga pernah terbit di Kairo.

Isu lain yang muncul dalam majalah Nurul Jaqin, 9 November 1936 misalnya memuat satu tulisan yang membahas persoalan Monotheisme yang sedang mendapat perhatian pada saat itu. Menurut penulis dalam tulisannya makna Monotheisme sebetulnya sudah lama dikenal dalam Islam yang berpadanan dengan kata tauhid dalam ajaran Islam. Selain itu satu majalah milik aliran Ahmadijah Qadijan bernama Islam terbit di kota Padang sejak tahun 1932-1939, majalah ini memuat perdebatan antara agama Islam dan Kristen. Persoalan poligami dalam Islam juga menjadi isu yang dimuat dalam satu tulisan di majalah Islam, No. 23, Thn. II, 1 November 1932.

Penulis dalam tulisan ini menganjurkan poligami dengan argumen agar laki-laki terhindar dari perbuatan zina dan merusak diri sendiri dan perempuan lain.

Umumnya surat kabar berbasis 
agama Islam ini dicetak dengan format buku. Meski termasuk dalam klasifikasi majalah, tetapi mereka menyebutnya dengan surat kabar, misalnya sebagaimana yang terlihat dari foto surat kabar Al-Bajan dan Al-I'Lam di bawah.

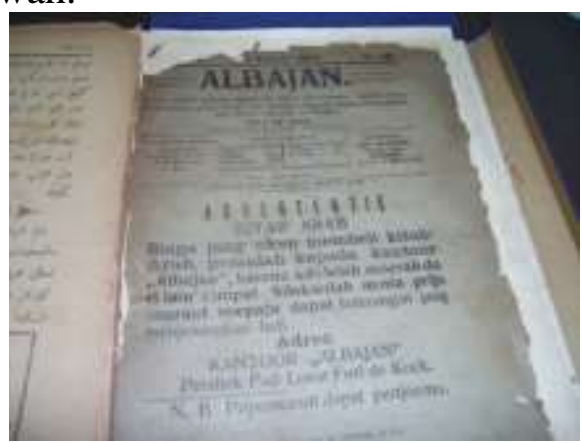

Foto 2. Surat kabar Al-Bajan

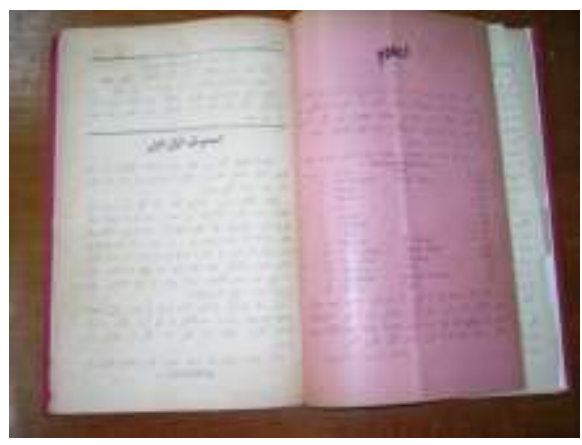

Foto 3. Surat kabar Al-I'Lam

Berdasarkan gambar foto di atas, kita bisa melihat penggunaan aksara Latin lebih diutamakan dalam iklan. Sedangkan aksara Arab Melayu digunakan dalam tulisan artikel, dan berita dalam surat kabar Al-Bajan. Penggunaan iklan dalam aksara Latin ini juga dapat kita temukan dalam surat kabar Al-Djauharah. Sedangkan Al-I'lam lebih fokus pada penggunaan aksara Arab Melayu dalam penerbitannya.

\section{PENUTUP}

Kehadiran surat kabar dan majalah berbasis Islam di Minangkabau dipelopori oleh kepulangan Kaum Mudadair Mesir dan Mekah yang membawa semangat pembaruan dalam bidang pendidikan dan pengetahuan agama. Revolusi mental yang mereka lakukan di bidang pendidikan adalah menerapkan metode pembelajaran modern dan terstruktur seperti penerapan sistem berkelas, membaca buku, dan menyediakan meja dan bangku di sekola. Upaya ini berhasil memberikan dampak positif dalam dunia pendidikan di Minangkabau yang selama ini masih bersifat tradisional yakni hanya mendengarkan guru bercerita di surau. Dan juga membangkitkan kesadaran keberaksaraan tinggi. Kehadiran 1300 siswa Sumatra Thawalib pada tahuntahun 1920-an merupakan bakal pembaca potensial di bidang keberaksaraan cetak di Minangkabau pada periode awal kebangkitan pers di sana.

Majalah Al-Moenir merupakan surat kabar Islam pertama yang kemudian disusul oeh berpuluh-puluh surat kabar dan majalah Islam lainnya yang membawa semangat nasionalisme dalam penyajian isi dan kandungan tulisan yang mereka terbitkan. Semangat nasionalisme yang termuat dalam kandungan tulisan di media cetak Islam di Minang pada masa itu banyak terinspirasi dari perkembangan nasionalisme di Timur Tengah seperti Mesir, Turki, dan juga India. Selain memuat semangat nasionalisme, surat kabar dan majalah Islam juga mengusung semangat Pan Islamisme dengan banyak menganjurkan persatuan dunia Islam, kemegahan dan kegemilangan Islam pada masa lalu dan membandingkannya dengan situasi pada saat itu. Umumnya pengarang mengutip sumber-sumber tulisan dari intelektual Muslim dunia, seperti, AlGazali, Abduh, Rashid Reza, Umar Qayyam, dan lain-lain. 


\section{DAFTAR PUSTAKA}

Abdullah, Taufik. 1966. "Adat And Islam: An Examination of Conflict In Minangkabau." Majalah Indonesia, No II, Oktober. Jakarta

1967. "Minangkabau 19001927: Preliminary Studies in Social Development"

1971. "Schools and Politics:

The Kaum Muda Movement in West Sumatra (1927-1933)". CMIP Monograph Series. (Ithaca: Cornell SEAP).

1972. "Modernization in the Minangkabau World; West Sumatra in the early decades of the 20th century", dalam Holt et al. (ed.)

Adam, Ahmad B. 2003. Sejarah Awal Pers dan Kebangkitan Kesadaran Keindonesiaan. Jakarta: Hastra Mitra.

Asnan, Gusti. 1987. "Pers Islam Di Sumatera Barat Pada Awal Abad XX: Suatu Gerakan Tinjauan Dalam Hubungannya Dengan Gerakan Pembaharuan". Skripsi Sarjana S-1 Jurusan Sejarah, Fakultas Sastra Universitas Andalas Padang.

Colombijn, Freek. 2006. Paco-Paco Kota Padang: Sejarah Sebuah Kota di Indonesia Abad ke-20 dan Penggunaan Tata Ruang Kota. Padang: Ombak.

Dobbin, Christine.2008. Gejolak Ekonomi, Kebangkitan Islam, dan Gerakan Padri:
Minangkabau

1784-1847.

Depok: Komunitas Bambu.

Eisenstein, Elizabeth L. 1979. The PrintingPress as an Agent of Change: Communication and Cultural Transformations in Early-Modern Europe volume I and II. Cambridge: Cambridge University Press.

Gallop, Annabel Teh. 1990. "Early Malay Printing: an Introduction to the British Library Collections". JMBRAS. LXIII (1): 85-124.

Graves. Elizabeth E. 2007.Asal-Usul Elite Minangkabau Modern:Respons Terhadap Kolonial Belanda Abad XIX/XX. Jakarta: Yayasan Obor Indonesia.

Naim, Asma dan Mochtar Naim. 1975, Bibliografi Minangkabau, Singapore: The Institute of Southeast Asian Studies.

Negoro, Adi. 1951. Falsafah Ratu Dunia (cetakan kedua). Jakarta: Balai Pustaka.

Noer, Deliar. 1982. Gerakan Modern Islam di Indonesia (1900-1942). Jakarta: LP3ES.

Putten, Jan van der. 1997. "Printing in Riau: Two Steps toward Modernity" dalam Bijdragen Tot De Taal-, Land-En Volkenkunde. No.153. Leiden: KITLV Royal Institute of Linguistics and Anthropology.

Rahzen, Taufik.2007. Tanah Air Bahasa:Seratus Jejak Pers Indonesia. Jakarta: I. Boekoe. 
Soebagijo I.N., H. 1977. Sejarah Pers Indonesia. Jakarta: Dewan Pers.

Surjomihardjo, Abdurachman. 1980.

Beberapa Segi Perkembangan Sejarah Pers di Indonesia. Proyek Penelitian Pengembangan dan Penerangan RI. Jakarta.

Suryadi. 2003. "Dunia Penerbitan dan Perbukuan di Sumatra Barat Sebelum Kemerdekaan". Melayu, Jurnal Antara Bangsa Dunia Melayu No. 1.

Sweeney, Amin. 1987. A Full Hearing: Orality And Literacy In The Malay World. Berkeley: University of California Press. 